наркотики або інші психоактивні речовини. Відзначаючи соціальнопедагогічну доцільність учинку студента можна підкреслити, що із професійного «погляду» він завдав шкоди дитині і не надав дійсно саме соціально-педагогічної допомоги ій. I в цьому разі його не виправдує навіть те, що він не знав про особливості життя «дітей вулиці». Цей метод, у сукупності з методом емпатії та іншими методами корекції суб'єктивного ставлення студентів до професійної діяльності, сприяє суб'єктификації об'єктів, стимулює усвідомлення студентом того, як його поведінка могла б «виглядати» 3 погляду людей, «інтересів» яких вона торкається. Цей метод відіграє одну із провідних ролей у корекції сформованого особистісно-значущого ставлення до професійної діяльності й створення мотивації вдосконалювання індивідуальних технологій взаємодії студентів з іншими людьми. Інакше кажучи, студент починає сам прагнути до того, щоб грамотно поводитись у соціумі відповідно до своєї професійної місією.

\title{
Література:
}

1. Дерябо С.Д. Природный объект как «значимый другой». Даугавпилс, 1995. 172c.

2. Ясвин В.А. Образовательная среда: от моделирования к проектированию. М: Смысл, 2001. 365с.

DOI https://doi.org/10.30525/978-9934-26-114-5-46

\section{АДАПТИВНА ТЕХНОЛОГІЯ НАВЧАННЯ ЕSР У ПОЛІКУЛЬТУРНИХ ГРУПАХ}

\author{
Добровольська Д. М. \\ кандидат філологічних наук, \\ доиент кафедри теорії та практики перекладу \\ Одеський національний університет імені I. I. Мечникова \\ Добровольська Л. В. \\ кандидат педагогічних наук, доцент, \\ доиент кафедри іноземних мов гуманітарних факультетів \\ Одеський начіональний університет імені I. І. Мечникова \\ м. Одеса, Украӥна
}

Сьогодні, коли світове суспільство висуває високі вимоги до фахівців промислових, сільськогосподарчих галузей народного 
господарства, а також суспільно-політичних інституцій: закладів освіти i охорони здоров'я, адміністративних та виконавчих організацій, засобів масової інформації тощо, кожен університет намагається створити сприятливі умови для надання якісної освіти. А загальний процес інтернаціоналізації вищої школи взагалі означає, що особи, які здобувають ступені бакалавра, магістра або навчаються в аспірантурі, $є$ представниками різних держав, національностей та національних меншин. Сказане вище, по-перше, означає, що кожна група студентів, фуркантів полікультурна; по-друге, що до вивчаємої в університеті іноземної мови висуваються вимоги не стільки як до мови академічного спрямування, скільки як до мови навчання для спеціальних цілей. Проте, професійно-орієнтоване навчання полікультурних груп має низку психолого-педагогічних особливостей. Серед них на перший план виступають загальні та особистісні характеристики здобувачів вищої освіти, що навчалися у різних країнах і вивчали іноземну мову за різними програмами. Тобто, навіть випускники закладів освіти одного року випуску мають розбіжності у номенклатурі засвоєних лексичних одиниць, граматичних конструкцій, семантикосинтаксичних прийомів декодування інформації письмових і аудитивних джерел. Крім того, як свідчать наші 10-річні спостереження, сформованість і усталеність навичок у тереневих видах мовленнєвої діяльності варіюються значною мірою від А1 до В2.

Одеський національний університет імені I.І.Мечникова (ОНУ), який за рейтингом вищіх навчальних закладів України 2021 року увійшов до першої п'ятірки кращих класичних вищів, а у загальному консолідованому рейтингу посів 8 місце серед 200 позначених навчальних закладів України [3], вже декілька десятиліть привертає увагу майбутніх здобувачів вищої освіти з Турції і В'єтнаму, Вірменії і Молдови, Сакартвело і Китая, Сгипту і Пакистану, Індії і Японії. Створено умови для комплектування полікультурних груп, при цьому кожна особистість скеровується при навчанні не тільки бажанням тримати грунтовні фахові знання, а також поліпшити або удосконалити знання іноземної мови: англійської, німецької, французької чи іспанської. Переважна більшість обирає англійську мову як іноземну, і ця стаття присвячена саме можливостям навчання ESP у полікультурних групах філологічного, філософського, історичного, математичного факультету та факультету міжнародних відносин.

Зазначимо, що розроблені в університеті програми фахового спрямування іноземної мови не передбачають окремого пропедевтичного курсу навчання, проте після тестування знань лексикограматичного матеріалу, вмінь та навичок у читанні, слуханні, письмі, 182 
усному мовленні студентів однієї академічної групи поділяють на 2-3 підгрупи за однаковими показниками виконання тестових (діагностичних) завдань. Це дає викладачам можливість приділяти додаткову увагу розвиненню занепадаючих навичок у тереневих видах мовленнєвої діяльності за рахунок виконання низки розроблених нами завдань. Усі завдання підпрядковані рецептивній текстовій діяльності, їх утворено на підгрунті текстів фахової спрямованості конкретного факультету.

Ми керуємося положенням про те, що текст як першоджерело фахової інформації і реальний продукт комунікації має значні переваги над окремими лексико-граматичними утвореннями, тому добирали автентичні статті з англомовних журналів, інтернет-сайтів світових університетів і наукових установ, так щоб вони віддзеркалювали тематику модулів навчальної програми. Дібрані автентичні матеріали разом з розробленими завданнями утворювали тезаурусно-тематичні цикли, що органічно «впліталися» в модульний матеріал і вивчалися групою на аудиторних заняттях (подробиці щодо принципів подання текстових матеріалів та розроблення завдань, послідовності роботи над формуванням мовних та мовленнєвих навичок студентів були висвітлені у кандидатській дисертації Л.В. Добровольської (Добровольська, 1992). Зрозуміло, що робота за нових глобальних реалій (COVID) потребувала удосконалення форм, методів, технологічних прийомів навчання англійської мови.

Враховувалися недостатньо розвинені у студентів-першокурсників навички знаходження у цілому тексті відповідей на так звані «упереджувальні» питання, при аудиторній роботі, наприклад, ми проекціювали на екран текст у вигляді окремих параграфів, після яких були 3 запитання (варіанти відповіді) на прогнозування інформації чи 3'ясування причинно-наслідкових зв'язків окремих частин тексту, як-то : It is implied in the passage that (варіанти відповіді подано); Which of the following is implied in the next paragraph of the text... ?; The paragraph preceding the passage most probably discussed (варіанти відповіді); The consequence of the information from the paragraph may be as follows (варіанти відповіді); Which of the mentioned above is most likely the topic of the following paragraph? [2].

Автентичну статтю було поділеного на 5-8 частин i надіслано студентам групи (по одній частині кожному студенту) для читання та підготовки для обговорення в аудиторії. На заняттях студенти обмінювалися здобутою інформацією, працюючи у малих групах. У разі роботи в ZOOM обговорення інформації проходило як 
фронтальна робота. Підсумковим результатом діяльності було написання нотаток чи тез усієї статті.

Самостійний пошук матеріалів для читання групи став одним iз улюблених завдань студентів, тим поче, що вони намагалися знайти статті про досягнення та наробки представників своєї країни, а це, 3 одного боку, підвищувало рівень інформованості, з другого - сприяло росту самовпевненості й авторитету у групі. Таку ж роль мали й презентації, зроблені окремими студентами чи малими групами, за тематикою модулів.

Для відтермінованого контролю знань, вмінь та навичок ми широко використовували можливості тестових завдань у Google Form, особливо коли академічні групи налічували 12-18 осіб.

На думку студентів, які навчалися за започаткованою нами технологією, аудиторна й позауадиторна робота над матеріалом курсу англійської мови була цікавою, привчала до самостійного пошуку, залучала до комунікації, показала позитивні риси спільної праці у полікультурному колективі. Ми вважаємо своїм основним надбанням таку технологію навчання англійської мови, яка пройшла апробацію і може однаково ефективно використовуватися в університеті як при контактній, так і при дистанційній формі занять.

\section{Література:}

1. Добровольська Л.В. Методика навчання читання літератури за фахом на основі серії градуйованих за труднощами текстів. Дис. канд. пед. наук. Київ. 1992. 245 с.

2. Добровольська Д. М. Добровольська Л.В.Технологія навчання іноземної мови при контактних та дистанційних формах роботи Актуальні питання гуманітарних наук. Index Copernicus -2020- Вип. 31. Дрогобич :ДДПУ.-С.139-1438

3. http://osvita/ua/vnz/rating/25713/?fbclid=IwAROjGH9AYB5cUM ntxtqLO3X-kcDL-CELPanPwTPrpeCwa-odSRegsc8eFQ4 